\title{
FREE RADICALS AND VITAMIN ANTIOXIDANTS IN HEALTH AND LUNG DISEASES
}

Narayan Gautam

\begin{abstract}
Several lung diseases have undergone oxidative stress due to free radical insult. Consequently, antioxidant vitamin $\mathrm{C}$ and vitamin E play important role in defense against cellular injury by scavenging free radicals. This article reviews the potential mechanism of free radicals generation and vitamin antioxidant defense to link amongst various lung diseases. One of the manifestations of free radical mediated process is lipid peroxidation subsequently producing malondialdehyde (MDA) in these patients. Supplementation of vitamin C and vitamin E as an adjuvant therapy as well as high intake of fresh fruits and vegetables appear to have a beneficial effect on lung health. Moreover, their consumption should be recommended on a daily basis. Further studies are needed to assess the impact of antioxidants as an adjuvant therapy in patients with lung diseases.
\end{abstract}

KEYWORDS: Lung disease; Free radical; antioxidant; oxidative stress; lipid peroxidation

\author{
For Correspondence \\ Narayan Gautam, \\ Associate Professor, \\ Department of Biochemistry, \\ Universal College of Medical College, \\ E-mail:ng_bp22@yahoo.com
}




\section{INTRODUCTION}

The biological chemistries of Reactive Oxygen Species (ROS) determine the ability of different species to react with specific cellular substrates within the microenvironment in which they are produced. A free radical is defined as any atomic or molecular species capable of independent existence that contains one or more unpaired electrons in one of is molecular orbitals. ${ }^{1}$ The most important ROS are superoxide anion $\left(\mathrm{O}_{2}^{-}\right)$, hydroxyl ion $(\mathrm{OH})$, nitric oxide ion $(\mathrm{NO})$ and hydrogen peroxide $\left(\mathrm{H}_{2} \mathrm{O}_{2}\right)$. The primary ROS formed in vivo are $\mathrm{O}_{2}^{-}$And $\mathrm{H}_{2} \mathrm{O}_{2}$. Accumulating evidence suggests that ROS aren't injurious by products of cellular metabolism but also essential participants of cell signaling and regulation ${ }^{2}$. The most reactive and harmful ROS is the $\mathrm{OH}$, which can be formed from $\mathrm{H}_{2} \mathrm{O}_{2}$ and superoxide, but also via the reaction of superoxide with $\mathrm{NO}$ to produce (OONO') (Fig.1) which decomposes to form $\mathrm{NO}_{2}$ and $\mathrm{OH}^{.}$.

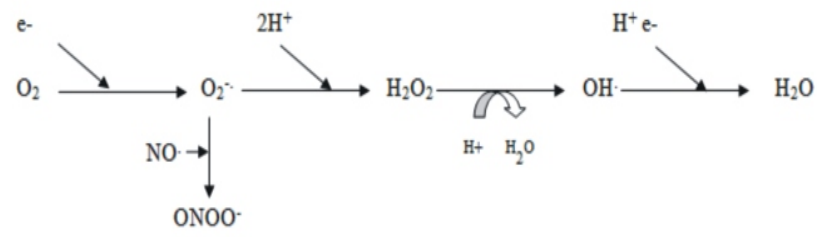

\section{Fig.1: The formation of ROS (Modified from Chabot et al, 1998)}

Unlike $\mathrm{O}_{2}, \mathrm{H}_{2} \mathrm{O}_{2}$ is not a free radical and is much more stable molecule. $\mathrm{H}_{2} \mathrm{O}_{2}$ is able to diffuse across biological membranes, whereas $\mathrm{O}_{2}^{-}$doesn't. $\mathrm{H}_{2} \mathrm{O}_{2}$ is as weaker oxidizing agent than $\mathrm{O}_{2}^{-}$ . Addition of exogenous $\mathrm{H}_{2} \mathrm{O}_{2}$ has been found to activate NK$\mathrm{kb}$. However, in the presence of transition metals such as iron or copper, $\mathrm{H}_{2} \mathrm{O}_{2}$ can give rise to the indiscriminately reactive and toxic hydroxyl radical $(\mathrm{OH})$ by Fenton chemistry. It can react with practically any molecule present in cells. For this reaction it is short lived. This insufficient stability does not allow it to diffuse through the cells. $\mathrm{OH}$ is the most potent among ROS, reacting with a wide range of macromolecules at a high rate constant ${ }^{4}$. $\mathrm{OH}$ is known to induce conformational changes in DNA including strand breaks, base modifications, damage to tumor suppressor gene and enhanced expression of protooncogenes ${ }^{5}$.

As there is a high concentration of mitochondrial SOD, the intra mitochondrial concentrations of $\mathrm{O}_{2}$ are maintained at very low steady state levels ${ }^{6}$. Thus unlike $\mathrm{H}_{2} \mathrm{O}_{2}$ which is capable of diffusing across the mitochondrial membrane into the cytoplasm ${ }^{7}$, mitochondria generated $\mathrm{O}_{2}^{-}$is unlikely to escape into the cytoplasm. Research demonstrated an increased production of $\mathrm{O}_{2}^{-}$during the proliferation of endothelial cells and involvement of species in the proliferation of B-lymphocytes ${ }^{8}$. There is an evidence to suggest that tumor necrosis factor (TNF)- $\alpha$ and Interleukin (IL)-1 induced apoptosis may involve mitochondria-derived ROS $^{9}$.

Smooth endoplasmic reticulum (ER) consisting cytochrome p-450 and b5 families of enzymes that can oxidize unsaturated fatty acids and xenobiotics and reduce molecular $\mathrm{O}_{2}$ to produce $\mathrm{O}_{2}^{-}$and/or $\mathrm{H}_{2} \mathrm{O}_{2}{ }^{10}$. Although it doesn't appear to be direct link between ER-derived oxidants and growth factor signaling, there is evidence for redox regulation of ER-related functions such as protein folding and secretion ${ }^{11}$. It has also been suggested that an $\mathrm{O}_{2}^{-}$generating microsomal NADH oxidoreductase may function as a potential pulmonary artery $\mathrm{O}_{2}$ sensor in pulmonary artery smooth muscle cells ${ }^{12,13}$.

Perioxisomes are an important source of total cellular $\mathrm{H}_{2} \mathrm{O}_{2}$ production. Perioxysomal catalase utilizes $\mathrm{H}_{2} \mathrm{O}_{2}$ produced by these oxidases to oxidize a variety of other substrates in peroxidative reactions $^{14}$. Another major function of the oxidative reactions carried out in peroxisomes is oxditation of fatty acids, which is mammalian cell, occurs in mitochondria and peroxisomes ${ }^{15}$.

In addition to intracellular membrane associated oxidases soluble enzymes such as xanthine oxidase, aldehyde oxidase, dihydroorotate dehydrogenase, flavoprotein dehydrogenase and tryptophan dioxygenase can generate ROS during catalytic cycling $^{16}$. Autoxidation of small molecules such as a dopamine, epinephrine, flavins and hydroquinones can be an important source of intracellular ROS production.

Although TNF- $\alpha$ stimulates oxidant production, the targets of TNF- $\alpha$ and oxidizing treatments can vary in different tissues. For example, analysis of TNF- $\alpha$ and $\mathrm{H}_{2} \mathrm{O}_{2}$ effects on different cell types revealed that TNF- $\alpha$ induced ICAM-1 and IL-8 mRNA expression in both lung epithelial cell line. Further analysis revealed that $\mathrm{H}_{2} \mathrm{O}_{2}$ activated AP-1 but not NF-Kb where as TNF- $\alpha$ activated both AP-1 and NF-Kb in the cell line ${ }^{16}$.

Plasma membrane associated oxidases have been implicated as the sources of most growth factor and/or cytokine stimulated oxidant production ${ }^{17}$, although the precise enzymatic sources have yet to be fully characterized. The best characterized of the plasma membrane oxidases in general is the phagocytic NADPH oxidase, which serves a specialized function in host defense against invading microorganisms. This multicomponent enzyme catalyses the one electron reduction of $\mathrm{O}_{2}$ and $\mathrm{O}_{2}^{-}$, with NADPH as the electron donor through the transmembrane protein cytochrome b588 (a heterodimeric complex of gp91 phox and p22 phox protein subunits). The transfer of electron occurs from NADPH on the inner aspect of the plasma membrane to $\mathrm{O}_{2}$ on the outside. During phagocytosis the plasma membrane is internalized as the well of the phagocytic vesicle, with what was once the 
outer membrane surface now facing the interior of the vesicle. This targets the delivery of $\mathrm{O}_{2}^{-}$and its reactive metabolites internally for localized microbicidal activity ${ }^{18}$.

When oxygen is partially reduced it becomes activated and reacts with a variety of biomolecules. ROS are also regarded as essential participants in cell signalling ${ }^{19}$ and gene regulation ${ }^{20}$. They play an important role in host defense, since active phagocytes generate ROS to fight foreign organisms especially through membrane bound NADPH oxidase, a situation that is often referred as the respiratory burst ${ }^{21}$. Respiratory burst is induced when phagocytes recognize microorganisms; but also by a wide variety of stimuli, including endotoxins, cytokines and fibrous materia $\mathrm{l}^{22}$.

Neutrophils have also shown to use myeloperoxidase (MPO), which uses $\mathrm{H}_{2} \mathrm{O}_{2}$ produced by dismutation of $\mathrm{O}_{2}^{-}$to oxidize chloride ions into hypochlorous acid ( $\mathrm{HOCl})$, which is a powerful antibacterial agent. ROS are also formed during reduction of molecular oxygen to water in cellular respiration in the mitochondrial electron transport chain, by the cycloxygenase pathway, and by cellular enzymes such cytochrome $\mathrm{P} 450$ oxidase and Xanthine oxidase.

The main sources of ROS in the lung include neutrophils, eosinophils and alveolar macrophages, but also alveolar epithelial cells, bronchial epithelial cells and endothelial cells are capable of generation superoxide and/or $\mathrm{H}_{2} \mathrm{O}_{2}^{23}$. Oxidant stress results, when ROS aren't adequately removed, and can lead to peroxidation of membrane lipids, depletion of nicotinamide nucleotides, rises in intracellular $\mathrm{Ca}^{++}$, cytoskeleton disruption and DNA damage ${ }^{5,24}$. ROS are highly toxic to all types of biological molecules including DNA, lipids, proteins and carbohydrates.

\section{MALONDIALDEHYDE (MDA)}

Malondialdehyde is the major reactive aldehyde resulting from the peroxidation of biological membrane polyunsaturated fatty acid (PUFA $)^{25}$. MDA is also a secondary product of LPO, used as an indicator of tissue damage by a series of chain reaction ${ }^{26}$. MDA is also a by-product of prostaglandin biosynthesis. It reacts with thiobarbituric acid produce red colored products. $\mathrm{OH}$ radical is the most reactive free radical species known and has the ability to react with a wide range of cellular constituents. For example, it will oxidize amino acid residues to produce schiff bases produce both strand breakage and chemical changes in the purine and pyrimidine bases of DNA and also attack membranes lipids to initiate a free radicals chain reaction known as lipid peroxidation. Increased amounts of ROS and RNI are produced as a consequence of phagocyte respiratory burst and serve as markers of the free radical mediated process. These ROS and RNI induce lipid peroxidation (LP), a chain process that effects unsaturated fatty acids mainly localized in cell membranes, in which product like MDA are generated, lipid peroxidation products (LPPs) diffuse from the site of inflammation and can measured in blood. MDA is a mutagenic and genotoxic agent that may contribute to the development of human cancer $^{27}$. Lipid hydroperoxides may directly induce DNA chain breaking ${ }^{28}$, and lipid peroxyl and alkoxyl radicals may cause base oxidation in $\mathrm{DNA}^{29}$.

\section{NITRIC OXIDE (NO) AND NITRIC OXIDE SYNTHASES}

Robert F Furchgott, Louis J Ignarro and Ferid Murad have got noble prize in medicine or physiology (1998) for discovering $\mathrm{NO}$ as signaling molecule. Nitric oxide has been associated with oxidant related to tissue injury by formation of highly reactive nitrogen intermediate via interactions with ROS. NO is a small, signal transducing molecule produced by various cells; for instance inflammatory cells, bronchial epithelial cells and vascular endothelial cells.

It is involved at least in the regulation of blood pressure and vasomotor tone, platelet aggregation and adhesion, neurotransmission and killing of bacteria, viruses and tumor cells. NO also reacts with superoxide and generates a highly active metabolite, peroxynitrite (OONO), which is presumed to be largely responsible for the most of the adverse effects of excessive generation of $\mathrm{NO}^{30}$. Since, reaction occurs at a nearly diffusion limited rate, it is assumed that $\mathrm{NO}$ can come out complete superoxide dismutases (SOD) for reaction with $\mathrm{O}_{2}^{-}$and that $\mathrm{OONO}^{-}$will be generated as a consequence of the simultaneous production of $\mathrm{O}_{2}$ and $\mathrm{NO}^{31}$. $\mathrm{NO}$ is endogenously produced in lung epithelial cells, alveolar macrophages, neutrophils and mast cells and the levels of NO may be modulated by $\mathrm{O}_{2}$ produced by neutrophils ${ }^{32}$.

Three forms of nitric oxide synthases has been described, neuronal (nNOS, NOS-1), inducible (iNOS, NOS-2) and endothelial (eNOS, NOS-3). nNOS and eNOS are constitutively expressed in neurons and endothelial cells, where as iNOS is induced by inflammatory cytokines through activation of NF-Kb in multiple cell types of human lung ${ }^{33}$. The induction of iNOS by inflammatory cytokines NO levels in exhaled air have been found elevated in wide variety of pulmonary disorders, such as lung cancer ${ }^{34}$, asthma ${ }^{35}$, sarcoidosis $^{36}$, adult respiratory distress syndrome (ARDS), bronchiectasis and alveolitis ${ }^{37}$.

\section{NON ENZYMATIC ANTIOXIDANTS}

Anerobic life is characterized as continuous production of oxidants balanced by equivalent synthesis of antioxidants ${ }^{38}$. A shift of the valance on the oxidant side may trigger a cascade of reaction leading to the formation of highly reactive cytotoxic compounds such as ROS. The improper balance between ROSs production and antioxidant defense results in 
"Oxidative Stress", which deregulates the cellular functions leading to various pathological conditions. The term antioxidant has been defined by Gutteridge and Halliwell ${ }^{39}$ as any substance that delays or inhibits oxidative damage to a target molecule. Low molecular weight antioxidant family consists of many compounds, each of which acts as a direct chemical scavengers neutralizing ROS components or indirect through transition metal chelation. Most of the low molecular weight antioxidants are reducing agents which quench ROS through donation of electron(s) to the ROS, neutralizing its activity ${ }^{40}$. Water-soluble antioxidants include vitamin $\mathrm{C}$, free GSH unrelated to its role in the GSH redox cycle, uric acid, glucose and taurine ${ }^{41}$. Also bilirubin, ubiquinol, flavonoids and dihydrolipoate have been suggested to have antioxidative capacities ${ }^{42}$. Vitamin E, or $\alpha$-tocopherol, is a lipid soluble antioxidant that can convert $\mathrm{O}_{2}^{-}, \mathrm{OH}$ and lipid peroxyl radicals to less reactive form. Also $\beta$-carotene, a carotenoid metabolic precursor to Vitamin A, is a lipid soluble antioxidant.

\section{VITAMIN C (ASCORBIC ACID)}

Vitamin C (ascorbic acid) is an important water-soluble antioxidant in biological fluids and an essential micronutrient required for normal metabolic functioning of the body ${ }^{43}$. Plasma ascorbate levels of 0.4 to $1.4 \mathrm{mg} / \mathrm{dl}$ reflect a daily ascorbate intake of $40 \mathrm{mg}$ or more in the adult. When tissues are saturated with vitamin $\mathrm{C}$, the plasma ascorbate concentrations are between 0.8 and $1.5 \mathrm{mg} / \mathrm{dl}$, the whole blood levels are between 1 to $1.5 \mathrm{mg} / \mathrm{dl}$ and the buffy coat ascorbic acid levels are between 25 to $35 \mathrm{mg} / \mathrm{dl}$. Higher plasma ascorbic acid concentration can be attained temporarily following the ingestion of a large dose of the vitamin C.

Human have no ability synthesize vitamin $\mathrm{C}$ due to mutation in the gene coding for L-gluconolactone oxidase an enzyme required for the biosynthesis of vitamin $\mathrm{C}$ via the glucuronic acid pathway ${ }^{44}$. Vitamin $\mathrm{C}$ is cofactor for several enzymes involved in the biosynthesis of collagen, carnitine, and neurotransmitters ${ }^{45}$. The temporal order of antioxidant consumption in human with blood plasma exposed to a constant flu of aqueous peroxyl radicals is vitamin C $>$ Bilirubin $>$ Uric acid $>$ Vitamin E. Plasma devoid of vitamin $\mathrm{C}$, but no other endogenous antioxidant is extremely vulnerable to oxidant stress and susceptible to perooxidative damage to lipids ${ }^{46}$. Vitamin C readily scavenges ROSs, Ozone, $\mathrm{ONOO}^{-}, \mathrm{NO}_{2}, \mathrm{NO}$ and hypochlorous acid ${ }^{47}$.

Transfer of one electron form ascorbic acid yields the unstable free radical intermediate semidehydroascorbic acid (half-life tie of $10^{-5}$ seconds); transfer of second electron results in dehdroascorbic acid. The ascorbate:dehydroascorbic acid couple is reversible; for example, dehydroascorbic acid can be reduced to ascorbic acid by sulfhydryl reagents. However, hydrolysis of dehydroascorbic acid to diketogulonic acid is irreversible.

\section{INTRACELLULAR FUNCTION OF VITAMIN C IN NEUTROPHILS, MONOCYTES AND LYMPHOCYTES}

Using oxygen as a starting material, neutrophils and monocytes generate oxidizing compound to kill bacteria. Ascorbate was proposed to be involved in oxidant generation. Although neutrophils form oxidants to kill bacteria, neutrophils must be part of the protective mechanisms, by reducing otherwise toxic oxidants ${ }^{48}$. Ascorbate was also proposed to be involved in chemotaxis or neutrophil movement. Paradoxically, ascorbate inhibits one of the reactions associated with chemotaxis, the addition of tyrosine to the microtubule protein tubulin ${ }^{49}$.

Ascorbic acid was accumulated against concentration gradients in neutrophils, extracellular ascorbate in micromolar concentration was accumulated in millimolar concentration by a high affinity transport activity. Each was saturable and temperature dependent ${ }^{50}$. Extracellular ascorbate could protect host tissues from oxidant damage by quenching destructive oxidants. Extracellular ascorbate is oxidized to dehydroascorbic acid. The increase in intracellular ascorbate occurs precisely the time when ascorbate is needed to protect against oxidants, many of which diffuse freely. Thus, extracellular ascorbate may protect host tissues; oxidized ascorbate is then recycled to protect neutrophils from their own oxidants.

Although oxidant quenching by antioxidant recycling could have an attractive hypothesis, antioxidant recycling could have other functions. As for example increased intracellular ascorbate could be used for regulating chemotaxis and/or phagocytosis, or increased oxidant generation. The last possibility may seem especially attractive since the isolated enzyme myeloperoxidase, necessary for hypochlorous acid formation utilizes ascorbate ${ }^{51}$. Myeloperoxidase is found in neutrophils granules, these granules fuse with the phagosome. Ascorbic acid in the phagosome would either be transported directly into the cytosol or oxidized to dehydroascorbic acid and the preferentially transported into the cytosol. It remains possible that electrons form ascorbate in cytosol are transferred to myeloperoxidase in phagolysomes via electron transfer protein.

\section{ANTIOXIDANT PROPERTIES OF VITAMIN C}

Vitamin C neutralizes ROSs and reduces oxidative DNA damage and genetic mutations. It has also been reported that vitamin $\mathrm{C}$ enhance host immunological functions. Vitamin C can protect lipid and lipoprotein against oxidative damage ${ }^{52}$. Vitamin $\mathrm{C}$ can act as a co-antioxidant by regenerating $\alpha$ tocopherol from the $\alpha$-tocopheryl radical produced during scavenging of $\mathrm{ROSs}^{53}$. Vitamin $\mathrm{C}$ has also been shown to 
regenerate urate, glutathione and beta-carotene in vitro or their respective one electron oxidation product i.e. urate radicals, glutathionyl radicals and beta carotene radicals cations ${ }^{54}$. Vitamin C may modulate the activity of hydroxymethyl glutaryl-CoA reductase, the rate-limiting enzyme in the biosynthesis of cholesterol. Although vitamin $\mathrm{C}$ also reacts rapidly with $\mathrm{OH}$ (Rate constant $>10^{-9} \mathrm{~L} \mathrm{~mol}^{-1} \mathrm{~S}^{-1}$ ), it is nevertheless unable to preferentially scavenge this radical over other substrates $^{55}$.

\section{VITAMIN E}

The term vitamin $\mathrm{E}$ describes a family of eight antioxidants, four tocopherols $\alpha, \beta, \gamma, \delta$ and their tocopherols is the only form of vitamin $E$ that is actively maintained in human body and is therefore, found in the largest quantities in the blood and tissue ${ }^{56}$. Although the antioxidant property of these molecules is similar, distinct biological effects can be distinguished at a molecular level. The specificity is the result of a selective retention of tocopherol in the body and the preferential interactions of some of the compounds with molecular components of the cells.

Because of its hydrophobicity, dietary vitamin E requires special transport mechanisms in the aqueous environment of the plasma, body fluids and cells. The tocopherols are assembled together with triglycerides, cholesterol, phospholipids and apolipoproteins into chylomicrons. During chylomicron lipolysis, a part of vitamin $\mathrm{E}$ is distributed to tissue. Over expression of lipoprotein lipase increases the transfer of tocopherol from chylomicrons into skeletal muscle cells $^{57}$. The other part is captured by the liver with the chylomicron remnants. In the liver, tocopherol is specifically recognized by the $32 \mathrm{KDa}$ tocopherol transfer protein (TTP), incorporated into very low density lipoproteins (VLDL), then transported and delivered to peripheral cells. The Low Density Lipoproteim and high-density lipoprotein (HDL) fraction combined contain $90 \%$ of total serum vitamin $\mathrm{E}$ in humans ${ }^{58}$. The plasma phospholipids transfer protein facilitates the exchange to tocopherol between LDL and HDL ${ }^{59}$.

In the lung, HDL is the primary source of vitamin E for type II pneumocytes, and its uptake is regulated by the expression of scavenger receptor SR-B ${ }^{60}$. In peripheral cells, the highest content $(150 \mu \mathrm{g} / \mathrm{g}$ tissue) is found in adipose tissue whereas erythrocytes have a relatively low content $(2 \mu \mathrm{g} / \mathrm{g}$ tissue $)$ of tocopherol $^{61}$.

\section{ANTIOXIDANT PROPERTIES OF TOCOPHEROL}

Although it is commonly believed that phenolic compounds like vitamin E exert a protective role against free radical damage antioxidant molecules can exert additional biological functions. Vitamin $\mathrm{E}$ is the major hydrophobic chain breaking antioxidant that prevents the propagation of free radical reactions in the lipid components of membranes, vacuoles and plasma lipoprotein. Vitamin E can directly act with a variety of oxy radicals, including the peroxy radical (ROO), $\mathrm{CCl}_{3}, \mathrm{OH}$, $\mathrm{O}_{2}$ and singlet oxygen ${ }^{62}$. Vitamin $\mathrm{E}$ donates hydrogen from the six position of its chromonal ring to the PUFA in the cell membrane. The phenolic hydroxyl group of tocopherol reacts with an organic hydroperoxides and tocopheryl radical.

The antioxidant properties of vitamin $\mathrm{E}$ are well known and documented $^{63}$. The enzyme PKC enzyme is responsible for the release of reactive oxygen species and lipid oxidation ${ }^{64}$. Vitamin E can protect the conjugated double bond of $\beta$ carotene form oxidation. The sparing action of tocopherol on $\beta$ carotene was described in vivo in humans by Urbach et $\mathrm{al}^{65}$. The sparing as well as synergistic actions are thought to result from the ability of both tocopherol and selenium-dependent GPx to decrease the productionLP.

(Vit E-O): $\mathrm{ROO}+\mathrm{Vit}$-OH $\quad \mathrm{ROOH}+\mathrm{Vit} \mathrm{E}-\mathrm{O}$

The chain of peroxidation reaction is effectively interrupted; the generated organic hydroperoxides can subsequently be detoxified via non-radical reaction. Tocopheroxyl radical can be reduced to tocopherol by interaction with reductants serving as hydrogen donors.

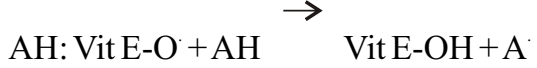

\section{EFFECTS OF TOCOPHEROLAT CELLULAR LEVEL}

In 1991 inhibition of PKC activity was found to be at the basis of vascular smooth muscle cell growth arrest induced by tocopherol $^{66}$. Many reports have subsequently confirmed by the involvement of PKC in the effect of tocopherol on different cell types. Including monocytes, macrophages, neutrophils, fibroblasts and mesangial cell ${ }^{67}$. Tocopherol, but not $\alpha$ tocopherol, was found to inhibit thrombin-induced PKC activation and endothelin secretion in endothelial cells ${ }^{68}$. Tocopherol inhibits the activity of PKC from monocytes, followed by inhibition of phosphorylation and translocation of the cytosolic factor phox 47 and by an impaired assembly of the NADPH-oxidase and of superoxide production ${ }^{69}$. Tocopherol has the important biological effect of inhibiting the release of the proinflammatory cytokine, IL-1 $\beta$, via inhibition of 5-lipoxygenase pathway.

Inhibition of PKC by tocopherol in vascular smooth muscle cells is observed to occur at concentration tocopherol close to those measured in healthy adults ${ }^{70}$. Inhibition of PKC activity by tocopherol occurs at a cellular level by producing dephosphorylation of the enzyme whereby $\alpha$-tocopherol is much less potent ${ }^{71}$. Dephosphorylation of PKC occurs via protein phosphatase $\mathrm{PP} 2 \mathrm{~A}$, which is activated by treatment with tocopherol ${ }^{72}$. 


\section{INVOLVEMENT OF ROS AND ANTIOXIDANTS STATUS IN PATHOGENESIS OF LUNG DISEASES}

In mycobacterial infection the interaction between macrophages and lymphocytes mediated by the cytokines seem to be the most important in host defense. Increased amounts of ROS and RNI are produced as a consequence of phagocyte respiratory burst and serve as markers of the free radical mediated processes. Free radical reactions have been suggested to play a contributory role in the fibrogenesis either directly or through inflammatory simuli ${ }^{73}$. Tissue injury irrelevant the cause almost certainly leads to oxidative stress which then possibly impairs the tissue injury. There is much evidence that LP during oxidative stress is common in inflammatory processes ${ }^{74}$. In the previous study, it has been demonstrated that LPPs were enhanced in serum of patients with pneumonia and gradually declined during recovery. Hull et $\mathrm{al}^{75}$ found that increased serum LPPs in children with cystic fibrosis were associated with the presence of pulmonary inflammation.

An increased oxygen burden in the lungs arises from the accumulation if inflammatory cells in the lower respiratory tract, including macrophages and neutrophils, which show an exaggerated release of oxygen radicals ${ }^{76}$ and these alveolar inflammatory cells have been shown to produce increased number of $\mathrm{O}_{2}^{-}$in patients with pulmonary fibrosis and pneumonocosis. The activities of SOD, CAT and GPx are decreased in beomycin-incuced fibrosis ${ }^{77}$ and ROS have been implicated in mediating fibroblast proliferation. It has been shown that LP increased synthesis of TGF- $\beta$ (transforming growth factor $\beta)^{78}$, which plays a key role in tissue repair and fibrogenesis $^{79}$. On one hand it stimulates synthesis of procollagen type I and fibronetin ${ }^{80}$, while on the other it down regulates the gene expression of collagenase ${ }^{81}$.

Reddy et $\mathrm{al}^{82}$ had shown significant correlation between high MDA concentrations and low concentrations of some antioxidants in the patients with pulmonary tuberculosis. Three of the antioxidants that were significantly reduced in tuberculosis patients i.e., glutathione ascorbic acid and $\alpha$ tocopherol, are integral component of a regenerating redox cycle $^{83}$. In untreated Ethiopians concentrations of antioxidant vitamin $C$, vitamin $E$ and vitamin A were significantly lower in tuberculosis patients and high malondialdehyde concentrations were associated with clinical severity ${ }^{84}$. Awotedu et $\mathrm{al}^{85}$ found decreased ascorbic acid concentration in pulmonary tuberculosis. Furthermore, increased production of ROS by activated neutrophils and decreased antioxidant capacity has been suggested to play a central role in the pathogenesis of ARDS ${ }^{86}$. Hyperoxia is known to cause oxidant injury and fibrosis in animals and in humans; it has been implicated as one of the major reason for bronchopulmonary dysplasia ${ }^{87}$.
Uzun et a ${ }^{88}$ have shown diagnostic value of malondialdehyde by measuring its level in the serum of patients with lung diseases with various etiologies also found significantly higher malondialdehyde level than control. ROS have also been suggested to play a role in smoking induced diseases, such as $\operatorname{COPD}^{89}$, and in addition to that, human lung fibroblasts recruit in respond to smoke extract which may suggests that ROS have a role in other cigarette smoke associated fibrotic lung disease. Important consequences of oxidative stress in the pathogenesis of COPD include oxidative inactivation of antiproteinases, air-space epithelial injury, increased sequestration of neutrophils in the pulmonary microvasculature and gene expression of proinflammatory mediators. Therefore, oxidative stress is assumed to pay an important role in the pathogenesis of a number of lung diseases like COPD, bronchial asthma, ARDS etc; not only through direct injurious effect but also by involvement in the molecular mechanisms that control lung inflammation.

Mycobacterium tuberculosis is capable of inducing ROS by activating both mononuclear and polymorphonuclear phagocytes that may possess antimicrobial activity ${ }^{90}$. The enhanced level of cytokines and free radicals production, although designed to combate the invader, has potential to damage host tissue. However, the host tissue damage is limited by concurrent enhancement of the antioxidants defense of the hosts. Number of studies have shown the poor antioxidant defense that may exposes oxidative stress to host tissue damage in PTB patients ${ }^{91,92,93,94,95,96}$.

\section{CONCLUSION}

Fresh fruits and vegetables contain large amount of vitamin C and carotenoids. The richest sources of vitamin $\mathrm{E}$ in the human diet are oil products such as vegetable and seed oil, mayonnaise, butter and eggs. Vitamin $\mathrm{C}$ appears to be the most abundant antioxidant substance in the extracellular fluid lining of the lung ${ }^{97}$ and contributes to the regeneration of membrane bound oxidized vitamin E. Vitamin C scavenges superoxide radicals $\mathrm{O}_{2}^{-}$and vitamin $\mathrm{E}$ breaks the lipid peroxidation chain reaction. The current recommended daily intake (RDI) for vitamin $\mathrm{C}$ is $75 \mathrm{mg}$ /day for women (100 $\mathrm{mg}$ /day for smokers) and $90 \mathrm{mg} /$ day for men $(125 \mathrm{mg} /$ day for smokers). Smokers required more doses due to additional oxidant exposure from smoking. The RDI for vitamin $\mathrm{E}$ is $15-$ $20 \mathrm{mg} /$ day. Antioxidant vitamins, particularly vitamin $\mathrm{C}$ with other antioxidant vitamins have a protective effect against lung diseases. Further randomized interventional studies with vitamin supplementations are needed to establish the impact of these antioxidant vitamins on the incidence and pattern of lung diseases. The observed reduction in plasma antioxidant vitamin $\mathrm{C}$ and $\mathrm{E}$ are primarily in response to enhanced oxidative stress with production of free radicals in various 


\section{REFERENCES}

1. Halliwell B, Gutteridge JMC. Free Radicals in Biology and Medicine. New York: Oxford University Press. 1989, 22-85.

2. Finkel T. Oxygen radicals and signaling. Curr Opin Cell Biol 1998; 10: 248-53.

http://dx.doi.org/10.1016/S0955-0674(98)80147-6

3. Halliwell B. Activation of molecular oxygen by flavins and flavoprotiens. J Biol Chem 1994; 269: 22459-62.

4. Hutchinson F. Chemical changes induced in DNA by ionizing radiations. Prog Nucleic Acid Res Mol Biol 1985; 32: 115. http://dx.doi.org/10.1016/S0079-6603(08)60347-5

5. Halliwell B, Aruoma OL. DNA damage by oxygen derived species: its mechanism and measurement in mammalian systems. FEBSlet 1991; 9: 282.

http://dx.doi.org/10.1016/0014-5793(91)80347-6

6. Tyler DD. Polarographic assay and intracellular distribution of superoxide dismutase in rat liver. Biochem J 1975; 147: 493-504. http://dx.doi.org/10.1042/bj1470493

PMid:810138 PMCid:PMC1165477

7. Chance B, Sies H, Boveris A. Hydroperoxide metabolism in mammalian organs. Physio Rev 1979; 59: 527-605.

PMid:37532

8. Morikava K, Moridawa A. Immunodeficiency effect of recombinant human superoxide dismutase (SOD) on human $B$ lymphocyte function in vitro. Cell Immunol 1996; 70: 172.

9. Sidoti-de Fraisse C, Rincheval V, Risler Y, Mignotte B, Vayssiere $J L$. TNF- $\alpha$ activates at least two apoptotic signaling cascades. Oncogene 1998; 17: 1639-51.

http://dx.doi.org/10.1038/sj.onc.1202094

10. Aust SD, Roeirg DL, Pederson TC. Evidence for superoxide generation by NADPH-cytochorme c reductase of rat liver microsomes. Biochem Biophys Res Commun 1972; 47: 1133-37. http://dx.doi.org/10.1016/0006-291X(72)90952-7

11. Bader M, Muse W, Ballou DP, Gassner C, Bardwell JC. Oxidative protein folding is driven by the electron transport system. Cell 1999; 98: 217-27.

http://dx.doi.org/10.1016/S0092-8674(00)81016-8

12. Mohazzab KM, Wolin MS. Sites of superoxide anion production detected by lucigenin in calf pulmonary artery smooth muscle. Am J Physio Lung Cel Mol Physiol 1994; 267:L815-L22.

13. Mohazzab KM, Wolin MS. Sites of superoxide anion production detected by lucigenin in calf pulmonary artery smooth muscle. Am J Physio Lung Cel Mol Physiol 1994; 267: L823-L31.

14. Tolbert NE, Essner E. Microbodies: Peroxisomes and glyoxysomes. JCell Biol 1981; 91: 271s-83s. http://dx.doi.org/10.1083/jcb.91.3.271s PMid:7033240
15. Alberts B, Bray D, Lewis J, Raff $M$, Roberts $K$, Watson JD. Molecular Biology of the Cell. New York: Garland, 1994: 653720 .

16. Freeman BA, Crapo JD. Biology of disease: free radicals and tissue injury. Lab Invest 1982; 42: 412-26.

17. Meier B, Radeke HH, Selle $S$, Younes $M$, Sies $H$, Resch $K$, Habermehl GG. Human fibroblasts release reactive oxygen species in response to interleukin-1 or tumor necrosis factor- $\alpha$. Biochem J 1989: 263:539-54.

http://dx.doi.org/10.1042/bj2630539

PMid:2556998 PMCid:PMC1133461

18. Babior BM. NADPH oxidase:an update. Blood 1999; 93: 14642147. PMid:10029572

19. Mossman BT. Signal transduction by oxidants: look who's talking. Free Rad Biol Med 2000; 28: 1315-16.

http://dx.doi.org/10.1016/S0891-5849(00)00217-3

20. Allen $R G$, Tresini M. Oxidative stress and gene regulation. Free Rad Biol Med 2000; 28: 463-99.

http://dx.doi.org/10.1016/S0891-5849(99)00242-7

21. Babior BM, Kipnes RS, Curnutte JT. Biological defence mechanisms. The production by leukocytes of superoxide, a potential bactericidal agent.JClin Invest 1973; 52: 741-44. http://dx.doi.org/10.1172/JCI107236 PMid:4346473 PMCid:PMC302313

22. Rossi F. The O2-. forming NADPH oxidase of the phagocytes: nature, mechanisms of activation and function. Biochem Biohys Acta 1986; 53: 65-89.

http://dx.doi.org/10.1016/0304-4173(86)90005-4

23. Hollamed JA, Pritchart KA, Pappolla MA, Wolin MS, Rogers NJ, Stermerman MB. Bradykinin induces superoxide anion release from human endothelial cells. JCell Physiol 1990; 143: 21-25. http://dx.doi.org/10.1002/jcp.1041430104 PMid:2156873

24. Wallis RS, Ellner JJ. Cytokine and tuberculosis. J Leukoc Biol 1994; 55: 676-81.

PMid:8182346

25. Vaca CE, Wilhelm J, Harms-Rihsdahl M. Interaction of lipid peroxidation product with DNA. Mutat Res Rev Genet Toxicol 1998; 195: 137.

http://dx.doi.org/10.1016/0165-1110(88)90022-X

26. Ohkawa H, Ohishi N, Yagi K. Assay for lipid peroxidation in animal tissues by thiobarbituric acid reaction. Anal Biochem 1979; 95: 351.

http://dx.doi.org/10.1016/0003-2697(79)90738-3

27. Feron VJ, Til HP, deVrjer F, Woutersen RA, Cassee FR, Van Bladeren PJ. Aldehydes: Occurrence, carcinogenic potential mechanism of action and risk assessment. Mutation Res 1991; 259: 363 .

http://dx.doi.org/10.1016/0165-1218(91)90128-9 
28. Cochrane CG. Cellular injury by oxidants. Am J Med 1991;91: 23.http://dx.doi.org/10.1016/0002-9343(91)90280-B

29. Park D. Peroxyl and Alkoxyl radicals cause DNA base modifications. Cancer Lett 1992; 28: 1235.

30. Beckman JS, Koppenol WH. Nitric Oxide, superoxide and peroxynitrite; the good, the bad and the ugly. Am J Physiol 1996; 271: $C 1424-C 37$

31. Jones KL, Bryan TW, Jinkins PA, Simpson KL, Grisham MB, Owens MW, Milligan SA, Markewitz BA and Robbins RA. Superoxide released from neutrophils causes a reduction in nitric oxide gas. Am J Physiol Lung Cell Mol Physiol 1998; 275: L1120-L26.

32. Robbins RA, Barnes PJ, Springall DR, Warren JB, Kwon OJ, Buttery LDK, Wilson AJ, Geller DA, Polak JM. Expression of inducible nitric oxide synthase in human lung epithelial cells. Biochem Biophys Res Commun 1994; 203: 209-15. http://dx.doi.org/10.1006/bbrc.1994.2169 PMid:7521161

33. Barnes PJ, M Karin. Nuclear factor- $\kappa B$ - a pivotal transcription factor in chronic inflammatory diseases. N Engl J Med 1997; 336: 1066-71

http://dx.doi.org/10.1056/NEJM199704103361506

PMid:9091804

34. Liu CY, Wang CH, Chen TC, Lin HC, UUCT, Kuo HP. Increased level of exhaled nitric oxide and up-regulation of inducible nitric oxide synthase in patients with primary lung cancer 1998; 78: $534-41$.

35. Kharitonov SA, Yates D, Robbins RA, Logan-Sinclair $R$, Shinebourne EA, Barnes PJ. Increased nitric oxide in exhaled air of asthmatic patients. Lancet 1994; 343: 133-35.

http://dx.doi.org/10.1016/S0140-6736(94)90931-8

36. Moodley YP, Chetty R, Lallo UG. Nitric oxide levels in exhaled in exhaled air and inducible nitric oxide synthase immunolization in pulmonary sarcodiosis. Eur Respir J 1999; 14: 822-27. http://dx.doi.org/10.1034/j.1399-3003.1999.14d17.x PMid:10573228

37. Lehtimaki L, Kankaanranta $H$, Saarelainen $S$, Hahtola P, Jarvenpaa R, Koivula T, Turjanmaa V, Moilanen E. Extended exhaled NO measurement differentiates between alveolar and bronchial inflammation Am J Respir Crit Care Med 2001; 163: 1557-61. http://dx.doi.org/10.1164/ajrccm.163.7.2010171 PMid:11401873

38. Rice-Evans CA, Diplock AT. Current status of antioxidant therapy. Free Rad Biol Med 1993; 15: 77.

http://dx.doi.org/10.1016/0891-5849(93)90127-G

39. Halliwell B, Gutteridge JMC. Role of oxygen free radicals and catalytic metal ions in human disease: an overview. Method Enzymol 1990; 186: 1 .

http://dx.doi.org/10.1016/0076-6879(90)86093-B

40. Chevion and Chevion. Antioxidant status and human health: use of cyclic voltametry for the evaluation of the anioxidant capacity of plasma and edible plants. Ann NY Acad Sci 2000; 899: 308-25. http://dx.doi.org/10.1111/j.1749-6632.2000.tb06196.x PMid:10863549

41. Heffner JE, Repine JE. Pulmonary strategies of antioxidant defense. Am Rev Respir Dis 1989; 138: 531-54.

http://dx.doi.org/10.1164/ajrccm/140.2.531

PMid:2669581

42. Fridovich I. fundamental aspects of reactive oxygen species, or what's the matter with oxygen? Ann NY Acad Sci 1999: 893:1318. http://dx.doi.org/10.1111/j.1749-6632.1999.tb07814.x PMid:10672226

43. Jaffe GM. Vitamin $C$, in handbook of vitamins, edited by $L$ Machilin (Marcel Dekker Inc, New York) 1997, 199

44. Woodall AA, Ames BN. Diet and oxidative damage to DNA: the importance of ascorbate as an antioxidant, in Vitamin $C$ in health and disease, edited by L Packer and J Fuchs (Marcel Dekker Inc, New York) 1997, 193

45. Burri BJ, Jaacob RA. Human metabolism and the requirement for vitamin $C$, in Vitamin $C$ in health and disease, edited by L Packer Packer and J Fuchs (Marcel Dekker Inc, New York) 1997, 341.

46. Frei B, England I, Ames BN. Ascorbate is an outstanding antioxidant in human blood plasma. Proc Natl Acad Sci USA 1989; 86: 81. http://dx.doi.org/10.1073/pnas.86.16.6377

47. Noroozi M, Angerson WJ, Lean MEJ. Effect of flavonoids and vitamin Con oxidative damage to human lymphocytes. Am J Clin Nutr 1998; 67:1210. PMid:9625095

48. Thomas EL, Learn DB, Jefferson MM. Weathered W. Superoxidedependent oxidation of extracellular reducing agents by isolated neutrophils. J Biol Chem 1988; 263: 2178-86. PMid:2828362

49. Halliwell B, Wasil M, Grootveld M. biologically significant scavenging of the myeloperoxidase-derived oxidant hypochlorous acid by ascorbic acid: implications for antioxidant protection in the inflammed rheumatoid joint. FEBS Lett 1987; 213: 15-17. http://dx.doi.org/10.1016/0014-5793(87)81456-4

50. Washko P, Tortosen D, Levine M. Ascorbic acid transport and accumulation in human neutrophils. JBiol Chem 1989; 264: 18996-19002. PMid:2681206

51. Marques LA, Dunford HB, Van Wart. Kinetic studies on the reaction of compound II of myeloperoxidase with ascorbic acid. $J$ Biol Chem 1990; $165: 5666-670$.

52. Frie B. Ascorbic acid protects lipids in human plasma and low density lipoprotein against oxidative damage. Am J Clin Nutr 1991; 54: S1113.

53. Packer L. Vitamin Cand redox cuclic antioxidants in Vitamin C in health and disease, edited by L Pacer Packer and J Fuchs (Marcel Dekker Inc, New York) 1997, 95.

54. Edge $R$, Truscott TG. Proxidant and antioxidant reaction 
mechanism of carotene and radical interaction with vitamin $E$ and C. Nutrition 1997; 13:992.

http://dx.doi.org/10.1016/S0899-9007(97)00346-8

55. Niki E, Noguchi N. Protection of human low-density lipoprotein form oxidative modification by vitamin $C$ in health and disease, edited by L Packer and J Fuchs (Marcel Dekker Inc, New York)1997, 183.

56. Evans HM. Bishop KS. Fetal resoption. Science 55650. Tocopherols in foods. Bauernfeind JB eds. Marcel Dekker New York. Vitamin E: Comprehensive Treatise 1980; 99- 167.

57. Sattler W, Levak Frank S, Radner H, Kostner GM, Zechner R. Muscle-specific overexpression of lipoprotein lipase in transgenic mice results in increased alpha tocopherol levels in skeletal muscle. Biochem J 1996; 318:15-19.

http://dx.doi.org/10.1042/bj3180015

PMid:8761445 PMCid:PMC1217581

58. Behrens WA, thompson JN, Madre R. Distribution of alphatocopherol in human plasma lipoproteins. Am J Clin Nutr 1989; 35: 691-96.

59. Kostner GM. Oettl K, JuahiainenM, Ehnholm C, Esterbauer H, Dieplinger H. Human plasma phospholipid transfer protein accelerates exchange/transfer of alpha tocopherol between lipoproteins and cells. Biochem J 1995; 305; 659-667.

http://dx.doi.org/10.1042/bj3050659

PMid:7832785 PMCid:PMC1136412

60. Kolleck I, Schlame M, Fechner H, Looman AC, Wissel H, Rustow $B$. HDL is the major source of vitamin $E$ for type II pneumocytes. Free Radic Biol Med; 1999; 27: 882-90. http://dx.doi.org/10.1016/S0891-5849(99)00139-2

61. Baurnfeind JC, Rubin SH, Surmatis JD, Ofner A. Carotinoids and fat-soluble vitamins: contribution to food, feed and pharmaceuticals. Int Z Vitaminforsch 2001; 40: 391-416.

62. Mc Cay $P B$. Vitamin $E$ : Interaction with free radical and ascorbate. Annu Rev Nutri 1985; 5: 323.

http://dx.doi.org/10.1146/annurev.nu.05.070185.001543 PMid:2992548

63. Esterbauer H, Schmidt R, Hayn M. Relationships among oxidation of low-density lipoprotein, antioxidant protection and atherosclerosis. Adv Pharmacol 1997; 38: 425-56.

http://dx.doi.org/10.1016/S1054-3589(08)60994-1

64. Bowry VS, Ingold KU, Stocker R. Vitamin E in human low-density lipoprotein. When and how this antioxidant becomes a prooxidant. Biochem J 1993; 288: 341-44.

http://dx.doi.org/10.1042/bj2880341

65. Urbach C, Hickman K, Harris PL. Effect of individual's vitamin $A, C, E$ and carotene administrated at high levels and their concentration in the blood. Exp Med Surg 2010; 151: 7.

66. Boscoboinik D, Szewcxuk A, Hesey C, Azzi A. Inhibition of cell proliferation by alpha-tocopherol. Role of protein kinase $C . J$ Biol Chem 1991; 266: 6188-194. PMid:2007576
67. Freedman JE. Farhat JH, Loscalzo J, Keaney JF, Loscalzo J, Keaney JF. Alpha-tocopherol inhibits aggregation of human platelets by a protein kinase C-dependent mechanism. Circulation 1996; 94: 2434-440.

http://dx.doi.org/10.1161/01.CIR.94.10.2434 PMid:8921785

68. Martin-Nizard F, Boullier A, Fruchart JC. Duriez P. Alphatocopherol by not beta tocopherol inhibi thrombin-induced PKC activation and endothelin secretion in endothelin secretion in endothelial cells. J Cardiovasc Risk 1998; 5: 339-45. http://dx.doi.org/10.1097/00043798-199810000-00010 http://dx.doi.org/10.1177/174182679800500510 PMid:9920007

69. Cachia O, Benna JE, Pedruzzi E, Descomps B, GougerotPocidalo MA, Leger CL. Alpha-tocopherols inhibis the respiratory burst in human monocytes. Attenuation of 477 (phox) membrane translocation and phosphorylation. J Biol Chem 1998; 273: 32801-805.

http://dx.doi.org/10.1074/jbc.273.49.32801 PMid:9830025

70. Gey KF. The antioxidant hypothesis of cardiovascular disease: epidemology and mechanisms. Biochem Soc Trans 1990; 18: 1041-45. http://dx.doi.org/10.1042/bst0181041

PMid:2088799

71. Ricciarelli R, Tasinato A, Clement S, Ozer NK. Boscoboinik D, Azzi A. Alpha-tocopherol specifically inactivates potencies of natural and synthetic antioxidants. J Org Chem 1998; 58: 3521532 .

72. Clement S, Tasinato A, BoscoboinikD, Azzi A. The effect of alphatocopherol on the synthesis, phosphorylation and activity of protein kinase downregulation. Eur J Biochem 1997; 246: 74549. http://dx.doi.org/10.1111/j.1432-1033.1997.t01-2-00745.x PMid:9219534

73. Poli $G$ and Parola M. Oxidative damage and fibrognesis. Free Rad Biol Med 1997; 22: 287-305.

http://dx.doi.org/10.1016/S0891-5849(96)00327-9

74. Mc Cord JM, Gao B. LeffJ, Flores SC. Neutrophil-generated free radicals: possible mechanism of injury in Adult Respiratory Distress Syndrome. Environ Health Perspect 1994; 102: 57-60. http://dx.doi.org/10.1289/ehp.94102s1057 http://dx.doi.org/10.2307/3432215

75. Hull J, Vervaart P, Grimwood K, Phelan P. Pulmonary oxidative stress response in young children with cystic fibrosis. Thorax 1997; 52: 557-60. http://dx.doi.org/10.1136/thx.52.6.557 PMid:9227724 PMCid:PMC1758593

76. Crystal RG. Oxidants and respiratory tract epithelial injury: pathogenesis and strategies for therapeutic intervention. Am J Med 1991; 91: 39S-44S. http://dx.doi.org/10.1016/0002-9343(91)90282-3

77. Slosman DO, Costabella PM, Roth $M$, Werlen $G$, Polla BS. Bleomycin primes monocytes-macrophages for superoxide production. Eur RespirJ 1990; 3: 772-78.

PMid:1702065 
78. Parola M, Muraca R, Dianzani I. Vitamin E dietary supplementation inhibits transforming growth factor $\beta 1$ gene expression in the rat liver. FEBS Lett 1992; 308: 267-70. http://dx.doi.org/10.1016/0014-5793(92)81290-3

79. Poli G, Parola M. Oxidative damage and fibrogenesis. Free Rad Biol Med 1997; 22: 287-305.

http://dx.doi.org/10.1016/S0891-5849(96)00327-9

80. Ignoz RA, Massague J. Transforming growth factor-stimulates the expression of fibronectin and collagen and their incorporation into the extracellular matrix. J Biol Chem 1986; 261: 4337-45.

81. Esward DR, Murphy G, Reynolds JJ, Whitham SE, Docherty AJP, Angel P, Health JK. Transforming growth factor beta modulates the expression of collagenase and metalloproteinase inhibitor. EMBOJ 1987; 6: 1899-1904.

82. Reddy YN, Murthy SV, Krishna DR, Prabhakar MC. Role of free radicals and antioxidants in tuberculosis patients. Indian $J$ Tuberc 2004; 51:213-18

83. Winkler BS, Orseli SM, Rex TS. The redox couple between glutatione and ascorbic acid: a chemical and physiological perspective. Free Radic Biol Med 1994; 17: 333-349.

http://dx.doi.org/10.1016/0891-5849(94)90019-1

84. Tesfaye Madebo, Bernt Lindtjorn, Pal Aukrust, Rolf K Berge. Circulating antioxidants and lipid peroxidaton products in untreated tuberculosis patients in Ethiopia. Am J Clin Nutr 2003; 78: $117-122$.

85. Awotedu AA, Sofowora EO, Elle SE. Acorbic acid deficiency in pulmonary tuberculosis. East African Medical Journal 1984; 61: 204-09.

86. Chobot F, Mitchell JA, Gutteridge JM, Evans TW. Reactive oxygen species in acute lung injury. Eur Respir J 1998; 11: 74557.

87. Jobi AH, Banclari E. Bronchopulmonary dysplasia. Am J Respir Crit Care Med 2001; 163: 1723-29.

http://dx.doi.org/10.1164/ajrccm.163.7.2011060

PMid:11401896

88. Uzun K, Vural H, Ozturk T, Ozer F, Imecik I. Diagnostic Value of Lipid Peroxidation in Lung Cancer. Eastern Journal of Medicine 2000; $2: 48-51$
89. Rahman I, Mac Nee W. Role of oxidants/antioxidants in smoking induced lung diseases. Free Rad Biol Med 1996; 21: 157-58. http://dx.doi.org/10.1016/0891-5849(96)00155-4

90. Kuo HP, Ho TC, Wang CH, Yu CT, Lin HC. Increased production of macrophages on patients with active pulmonary tuberculosis. Tuber Lung Dis 1996; 77: 468-75.

http://dx.doi.org/10.1016/S0962-8479(96)90122-7

91. Plit MI, Theron AJ, Ficki H, Van Rensburg CE, Pendel S, Anderson E. Influence of antimicrobial chemotherapy and smoking status on the plasma reactants, iron and lipid peroxides in patients with pulmonary tuberculosis. Int J Tuberc Lung Dis 1998; 2:590-96. PMid:9661828

92. Jack CI, Jackson MJ, Hind CR. Circulating markers of free radical activity in patients with pulmonary tuberculosis. Tuber Lung D 1994; 75:132-37

http://dx.doi.org/10.1016/0962-8479(94)90042-6

93. Grimble RF. Malnutrition and the immune response \& Impact of nutrients on cytokine biology in infection. Trans R Soc 1994; 88 : $615-19$.

94. Evans P, Halliwell B. Micronutrients: oxidant/antioxidant status. BrJNutr 2001; 85: S67-S74.

http://dx.doi.org/10.1079/BJN2000296 PMid:11509092

95. Lamsal M, Gautam N, Bhatta N, Toora BD, Bhattacharya SK, Baral N. Evaluation of lipid peroxidation product nitrite and antioxidant levels in newly diagnosed and two months follow-up patients with pulmonary tuberculosis. South East Asian J Trop Med Public Health 2007; 38(4): 695-703.PMid:17883009

96. Gautam N, Jayan A, Dubey RK, Jha SK, Dhakal PK, Baral N, Lamsal M. Comparative Study of Impact of Smoking in Healthy and Pulmonary Tuberculosis patients measured by Indices of Oxidative Stress. International Journal of Medical Sciences and Biotechnology 2013; 1(4): 45-54.

97. Hatch GE. Asthma, inhaled oxidants and dietary antioxidants. Am J Clin Nutr 1995; 61: S625-S30. 